\title{
Measuring Consumer Attitudes toward Money
}

\section{G G Rousseau}

Department of Industrial Psychology, University of Port Elizabeth

D J L Venter

Institute for Statistical Consultation and Methodology, University of Port Elizabeth

\begin{abstract}
The main objective of this study is to compare attitudes toward money amongst English, Afrikaans and Xhosa-speaking consumers in the Eastern Cape. Based on literature in the field, hypotheses were generated for four dimensions of a money attitude scale (MAS) developed by Yamauchi and Templer. The scale was modified and applied to a convenience sample $(\mathrm{N}=326)$ of respondents in the Port Elizabeth/Uitenhage area. Results showed significant differences between the various groups for three of the four dimensions of the scale. Results further suggest that the money attitude scale is a reliable instrument for measuring consumer attitudes toward money in South Africa. Implications are that more attention should be paid to educating consumers in the Eastern Cape on personal money management.
\end{abstract}

JEL Z10

\section{INTRODUCTION}

Private consumption expenditure is an important element of total demand in the economy. In South Africa, more than 50 per cent of the gross domestic product (GDP) is consumed by private individuals. In this way, private consumption expenditure can play a decisive role in the economic fortunes of any country. Ultimately, private consumption expenditure is influenced by both the ability and willingness to spend. As far as ability to spend is concerned, real disposable income is the most important determining factor. Willingness to spend or save depends to a large extent on levels of confidence or lack thereof which individuals hold of an economy (Du Plessis, Rousseau \& Blem, 1995).

Looking at the current South African demographic situation, a trend emerges of the higher income groups ageing while the lower income groups are still relatively young. The latter, which represent the largest segment of the population, are net borrowers of money. Their need for education, increased life expectations and relatively low per capita income, make their ability to save 
minimal with most money spent on necessities. The middle income economically active segment of the population also shows a low saving pattern. Due to the high inflation rates of the 1980 s, consumers fell into the habit of living on credit to maintain their living standards. This lead to a drop in the savings ratio from $10.8 \%$ in 1980 to $2.6 \%$ in 1992 . Currently it is estimated that private household debt in relation to personal disposable income is as high as $66 \%$. In 1992 it was only $53 \%$ and in $1987,43 \%$ (Swart, 1997).

The argument that people in the poor rural communities do not have surpluses available for saving, is generally untrue according to Davel (1996). Access to saving facilities is often the real problem. Many banks will not allow savers to open accounts without proof of employment which excludes anyone with their own informal sector business. Other institutions such as Peoples Banks place a minimum initial deposit requirement of $\mathrm{Rl} 000,00$ on its club accounts. The author concludes that the demand for appropriately structured saving facilities is not being met, resulting in the existence of a number of illegal banks specialising in the deposit mobilisation at the lower end of the market. This trend further inhibits confidence in saving behaviour.

From the above, it seems as though there is a decreasing trend in the saving patterns and investment contributions amongst South African consumers. This has put the country's economy in a very vulnerable position as economic growth now relies heavily on foreign investments. From a consumer affairs standpoint, it is of interest to know how consumers view money, and whether different ethnic groups such as Xhosa speaking, English and Afrikaans speaking consumers display different attitudes towards money and saving behaviour.

\section{CONCEPTUALISATION OF ATTITUDES TO MONEY}

Many conceptualisation studies of money attitudes by economists (Finn, 1992), anthropologists (Crump, 1992), sociologists (Baker \& Jimerson, 1992) and psychoanalysts (Bomemann, 1977 and Doyle, 1992) have despite their different approaches, concluded that understanding behaviour related to money is hardly rational; it is rather the result of powerful and often unrecognised (emotional) forces that reside deep in the psyches of individuals. William Kaufman (1997) states that the symbolic meaning of money to the individual and the manner in which he uses it, are determined by his culture, religion, the attitudes of parents and teachers, his life experiences (including the impact of the media of mass communication), the example of the people he knows and by his short and longterm goals. 
Penaloza (1994) in a study on Mexican immigrants' acculturation, found that knowledge of financial options and terms as well as trust in financial institutions affected their use of financial services. There was much confusion between bank and retail store credit cards. Immigrants were not familiar with American money; they found it strange that a little coin (a dime) could be worth more than a nickel. Many Mexican immigrants also associated credit with American materialism of which they disapproved. These findings reflect the important role of culture in people's perceptions and attitudes towards money.

Much of what we call emotional security is soundly backed by the proper uses of money. Even part of what we call love and affection in parents stems from their ability to spend wisely for the benefit of their children. The proper use of money creates the individual a sense of well-being and emotional security. Many individuals however also develop emotional and psychosomatic disorders (compulsive spending, gambling, unethical and illegal activities) as a result of their inability to cope with money problems or failure in business transactions.

There seems to be a consensus among scholars that attitudes towards money are a complex multidimensional concept that elicit both positive (e.g. freedom, love, success) and negative (e.g. distrust, inadequacy, failure) feelings in people. It further seems as though the emotional and psychological value of money for many consumers, far exceeds its relative economic (rational) value (Medina, Saegert and Gresham, 1996).

\section{EMPIRICAL STUDIES ON MONEY ATTITUDES}

Empirical research in the field has focused mainly on developing a suitable instrument for measuring money attitudes as well as comparing the attitudes of different cultural groups towards the construct. Yamauchi and Templer (1982) developed the original MAS (money attitude scale) and claimed that attitudes towards money are essentially independent of a person's income. Gresham and Fontenot (1989) refined the money attitude scale and applied it to a group of Mexican-Americans and Anglo-Americans. Medina, Saegert and Gresham (1996) in a follow-up study identified four factors along the money attitude scale, namely, power/prestige, retention/time, distrust/anxiety and quality. Mexican Americans scored lower than Anglo-Americans on the retention/time and quality factors.

Another scale termed a Money Ethic Scale (MES) was developed by Thomas Tang (1992) to test the influence of demographic variables such as age and gender on the management of money. The author found a relation between age and attitude towards money. In a follow-up study (Tang, 1993), differences and 
similarities were found between a sample of Chinese and American workers in their attitudes to money. Six factors emerged from the money ethic scale, namely, good, evil, achievement, respect, budget and freedom. Tang concludes that income, work ethic, social, political and religious values have a strong influence on how people perceive money.

In South Africa, Visser (1977) investigated possible differences between the meaning of money amongst students at the University of Western Cape and the University of Stellenbosch. The author applied fifteen dimensions of the semantic differential attitude scale to a sample of 128 White students and 102 Coloured students. No difference in the global meaning of money between the two groups were found, suggesting that both groups held closer views on the value of money than were initially expected.

Rousseau (1996) found price consciousness and bargain hunting to be two of five main factors influencing levels of consumer awareness amongst all population groups in South Africa. The influence of certain demographic variables such as age and income however impacted on these factors. Price consciousness, for example, was highest amongst respondents in the low to middle income categories and the older age brackets. They were mainly females. Bargain hunting again featured prominently amongst larger households in the low-income category.

From the above overview, it seems as though socio-demographical variables like culture, income, age and gender may well relate to money attitudes. The main objective of this study is to compare attitudes towards money amongst three language groups in the Eastern Cape province of South Africa. These groups represent different cultural backgrounds which may impact on their attitudes towards money. The present study used a similar version of the money attitude scale (MAS) applied by Medina, Saegert and Gresham (1996) in their comparison of Mexican and Anglo American's attitudes towards money. Based on previous research in the field, the following design hypothesis was set: There are significant differences between the attitudes towards money amongst the three language groups in the sample.

\section{METHOD}

The item scale developed and used in previous studies (Yamauchi \& Templer, 1982; Gresham \& Fontenot, 1989 and Medina, Saegert and Gresham, 1996) were modified for application in South Africa. The scale was reduced from a seven point to a five point rating scale. Malhotra (1996) suggest that in developing countries such as South Africa, preference should be given to less 
sophisticated scales like ordinal or simplified interval scales. Opinion formation may not be well crystallised in these countries due to a lower level of education and consumer sophistication. The questionnaire was translated from the original English version into Afrikaans and Xhosa to accommodate respondents from these language groups too. In order to avoid translation errors, the procedure of back-translation as suggested by Malhotra, Agarwal \& Peterson (1996) was followed.

The money attitude scale is a 30 -item scale that measures attitudes towards four money dimensions, namely, power/prestige, retention/time, distrust/anxiety and quality. To determine whether these four previously identified factors can be calculated accurately and reliably using the original 30 items, item analysis was performed for each of the factors individually.

The analyses were performed to:

(i) determine whether any items should be excluded, which was done by means of principal component factor analysis and item versus scale minus item correlations;

(ii) test the reliability of factors by means of Cronbach's coefficient alpha.

One way analysis of variance and Pearson t-tests were used to determine the statistical significance of differences in factor scores between various levels of the demographic variables. Analysis of variance was used to identify the demographic variables which were significantly related to factor scores.

Sample: A non-probability convenience sample $(\mathrm{N}=326)$ was drawn from the Port Elizabeth/Uitenhage metropolis is. The sample though was stratified to include all the important sub-populations in the area. Respondents were selected from the upper, middle and lower income groups residing in various suburban areas and townships in the region. They were also representative of the three main languages spoken in the province.

Procedure: Fieldwork was carried out by students of the University of Port Elizabeth and officials of the Consumer Protection Office in Port Elizabeth. All the fieldworkers were properly briefed on sample selection and interview procedures. Households in various residential areas were chosen for interviewing. Only one respondent per household, either husband or wife, completed the questionnaire. Consumers from the selected households completed questionnaires in their home language (English, Afrikaans or Xhosa). In cases where respondents did not understand a question, they were allowed to 
compare the phrasing with that of a questionnaire printed in one of the other languages.

Respondents were asked to rate each of the thirty items in the questionnaire on a five point Likert type scale ranging from agree completely to disagree completely. Field workers explained to respondents that there were no right or wrong answers to the questions in the questionnaire. The only answer that was important was the one that gave a true reflection of how the respondent felt about the question. Demographic information was also obtained from respondents regarding household size, income, age, education and gender.

Data analysis: Data analysis employed the computer programme BMDP 4M (Frane, Jenrich \& Samson, 1985) to perform factor analysis of the item sample. The method of principal component analysis was used with direct quartimin rotation. The BMDP programme $4 \mathrm{M}$ was also used to calculate item versus scale-minus-item Pearson Moment correlations. Cronbach's coefficient alpha was also calculated to determine reliability of the various sub-scales.

The BMDP programme 1D was then used to calculate mean factor scores for the various socio-demographic variables. These results are shown in Table 3. Programme $2 \mathrm{~V}$ was subsequently used to perform analysis of variance (ANOVA) to investigate which of the socio-demographic variables are significantly related to the various factors. These results are shown in Table 4. To test the statistical significance of factor score differences between the various socio-demographic groups (including language groups) one way analysis of variance (ANOVA program 7D) and Pearson t-tests (program 3D) were performed. These results are also summarised in Table 3.

\section{RESULTS}

Table 1 shows the descriptive statistics and correlations. 
Table 1 Descriptive statistics and correlations

\begin{tabular}{|l|l|l|l|l|l|l|c|}
\hline \multicolumn{9}{|c|}{} & Mean & S.D. & 1 & 2 & 3 & 4 \\
\hline 1 & $\begin{array}{l}\text { Power } \\
\text { Prestige }\end{array}$ & 2.1963 & 0.9620 & - & $0.1527^{* *}$ & $0.3844^{* *}$ & $0.1707^{* *}$ \\
\hline 2 & $\begin{array}{l}\text { Retention } \\
\text { Time }\end{array}$ & 3.5758 & 0.9268 & $-0.1527^{* *}$ & - & $0.1948^{* *}$ & $0.1137^{*}$ \\
\hline 3 & $\begin{array}{l}\text { Distrust } \\
\text { Anxiety }\end{array}$ & 3.1322 & 0.7295 & $0.3844^{* *}$ & $0.1948^{* *}$ & - & $0.1474^{* *}$ \\
\hline 4 & Quality & 3.5758 & 0.9268 & $0.1707^{* *}$ & $0.1137^{*}$ & $0.1474^{* *}$ & - \\
\hline
\end{tabular}

$N=326$

* significant at $95 \%$ C.L. $(r>=0.1090)$

** significant at $99 \%$ C.L. $(r>=0.1425)$

As can be seen from the table, moderate significant positive correlations between all factors occur except between power/prestige and retention time. A possible explanation for the negative correlation in the latter case may be the fact that respondents who regard money as a powerful prestige factor, may view saving and money retention for the future as less important. People want the material benefit of money now, therefore, they rather spend than save it for future benefit.

Table 2 shows the four factor analyses performed, one for each factor. Direct quartimin rotation and principal component extraction was used. The analyses confirmed that all items loaded significantly on the applicable scale, the lowest factor loading being 0.317 . The Cronbach's alphas for factors one, two and three were all above 0.70 while for factor four, the value of 0.69 can also be regarded as acceptable. This confirms the reliability of the four scales.

The percentage of total variance explained by factors one, two and four are all acceptable. For factor three, factor analysis indicated that the scale may be subdivided into two sub-scales, but for reasons of comparison with previous research, the sub-division was not affected.

Table 3 shows matrices of factor mean scores for demographic variables obtained from the sample and also indicates which factor score differences between the various socio-demographic categories are significant. In the table a low score indicates a negative response while a high score indicates a positive response. (The five point rating scale used in the questionnaire comprised verbal anchor points ranging from agree completely to disagree completely.) 
Table 2 Oblique rotated factor matrix: Measures of money attitudes

\begin{tabular}{|c|c|c|c|c|}
\hline Criterion & \begin{tabular}{|l|} 
Factor 1 \\
Power/ \\
Prestige
\end{tabular} & $\begin{array}{c}\text { Factor } 2 \\
\text { Retention/ } \\
\text { Time } \\
\end{array}$ & \begin{tabular}{|l|} 
Factor 3 \\
Distrust// \\
Anxiety
\end{tabular} & $\begin{array}{l}\text { Factor } 4 \\
\text { Quality } \\
\end{array}$ \\
\hline Item & & & & \\
\hline $\begin{array}{l}\text { 1. I tend to judge people by their money } \\
\text { rather than their deeds }\end{array}$ & 0.750 & & & \\
\hline $\begin{array}{l}\text { 2. I behave as if money were the ultimate } \\
\text { symbol of success }\end{array}$ & 0.697 & & & \\
\hline $\begin{array}{l}\text { 3. I find that I seem to pay more respect } \\
\text { for those people who possess more } \\
\text { money than I do }\end{array}$ & 0.700 & & & \\
\hline $\begin{array}{l}\text { 4. I own smart things in order to impress } \\
\text { others }\end{array}$ & 0.788 & & & \\
\hline $\begin{array}{l}\text { 5. I purchase things because I know they } \\
\text { will impress others }\end{array}$ & 0.741 & & & \\
\hline $\begin{array}{l}\text { 6. People that know me tell me that I } \\
\text { place too much emphasis on the } \\
\text { amount of money people have, as a } \\
\text { sign of their success }\end{array}$ & 0.737 & & & \\
\hline $\begin{array}{l}\text { 7. I enjoy telling people about the money } \\
\text { I make }\end{array}$ & 0.654 & & & \\
\hline $\begin{array}{l}\text { 8. I try to find out if other people make } \\
\text { more money than I do }\end{array}$ & 0.706 & & & \\
\hline $\begin{array}{l}\text { 9. I put money aside on a regular basis for } \\
\text { the future }\end{array}$ & & & & \\
\hline 10. I do financial planning for the future & & 0.753 & & \\
\hline 11. I save now to prepare for my old age & & 0.751 & & \\
\hline $\begin{array}{l}\text { 12. I have money available in the event of } \\
\text { an economic depression }\end{array}$ & & 0.625 & & \\
\hline 13. I follow a careful financial budget & & 0.740 & & \\
\hline 14. I am cautious with the money I spend & & 0.624 & & \\
\hline $\begin{array}{l}\text { 15. I keep track of my money } \\
\text { 16. It bothers me when I discover I could }\end{array}$ & & 0.607 & 0.461 & \\
\hline $\begin{array}{l}\text { 17. I complain about the cost of things I } \\
\text { buy }\end{array}$ & & & 0.478 & \\
\hline $\begin{array}{l}\text { 18. I show worrisome behaviour when it } \\
\text { comes to money }\end{array}$ & & & 0.680 & \\
\hline $\begin{array}{l}\text { 19. I worry about not being financially } \\
\text { secure }\end{array}$ & & & 0.664 & \\
\hline
\end{tabular}




\section{Table 2 continued}

\begin{tabular}{|c|c|c|c|c|}
\hline Criterion & $\begin{array}{c}\text { Factor } 1 \\
\text { Power/ } \\
\text { Prestige }\end{array}$ & \begin{tabular}{|c|} 
Factor 2 \\
Retention/ \\
Time
\end{tabular} & \begin{tabular}{|c|} 
Factor 3 \\
Distrust/ \\
Anxiety \\
\end{tabular} & $\begin{array}{l}\text { Factor } 4 \\
\text { Quality }\end{array}$ \\
\hline $\begin{array}{l}\text { 20. When I make a major purchase I have a } \\
\text { suspicion that I've been taken } \\
\text { advantage of } \\
\text { 21. I show signs of anxiety when I don't } \\
\text { have enough money } \\
\text { 22. After buying something, I wonder if I } \\
\text { could have got the same for less } \\
\text { elsewhere } \\
\text { 23. I hesitate to spend money, even on } \\
\text { necessities } \\
\text { 24. It is hard for me to refuse a bargain } \\
\text { 25. I automatically say "I can't afford it" } \\
\text { whether I can or not } \\
\text { 26. I am willing to spend more to get the } \\
\text { very best } \\
\text { 27. I buy top-of- the-line products } \\
\text { 28. I buy national brand products } \\
\text { 29. I pay more for some things because I } \\
\text { know I have to in order to get the best } \\
\text { 30. I buy the most expensive items } \\
\text { available }\end{array}$ & & & $\begin{array}{l}0.526 \\
0.317 \\
0.483\end{array}$ & $\begin{array}{l}0.643 \\
0.790 \\
0.618 \\
0.705 \\
0.591\end{array}$ \\
\hline $\begin{array}{l}\text { Percentage of total variance explained } \\
\text { Cronbach's coefficient alpha }\end{array}$ & $\begin{array}{c}52.2 \% \\
0.87\end{array}$ & $\begin{array}{c}49.0 \% \\
0.82\end{array}$ & $\begin{array}{c}30.8 \% \\
0.74\end{array}$ & $\begin{array}{c}45.3 \% \\
0.69\end{array}$ \\
\hline Sample size $N=326$ & & & & \\
\hline
\end{tabular}


Table 3 Descriptive statistics by language, household size, income, age, education and gender

\begin{tabular}{|c|c|c|c|c|c|c|c|c|c|}
\hline & \multirow[b]{3}{*}{$\mathbf{N}$} & \multirow{2}{*}{\multicolumn{2}{|c|}{$\begin{array}{l}\text { Factor 1 } \\
\text { Power/ } \\
\text { Prestige }\end{array}$}} & \multirow{2}{*}{\multicolumn{2}{|c|}{$\begin{array}{l}\text { Factor } 2 \\
\text { Retention/ } \\
\text { Time }\end{array}$}} & \multirow{2}{*}{\multicolumn{2}{|c|}{$\begin{array}{l}\text { Factor } 3 \\
\text { Distrust/ } \\
\text { Anxiety }\end{array}$}} & \multirow{2}{*}{\multicolumn{2}{|c|}{$\begin{array}{l}\text { Factor 4 } \\
\text { Quality }\end{array}$}} \\
\hline & & & & & & & & & \\
\hline & & MEAN & SD & MEAN & SD & MEAN & SD & MEAN & SD \\
\hline $\begin{array}{l}\text { Language: } \\
\text { Afrikaans } \\
\text { English } \\
\text { Xhosa }\end{array}$ & $\begin{array}{r}73 \\
157 \\
96 \\
\end{array}$ & $\begin{array}{l}1.68 \mathrm{a} \\
2.04 \mathrm{~b} \\
2.84 \mathrm{c} \\
\end{array}$ & $\begin{array}{l}0.76 \\
0.91 \\
0.84\end{array}$ & $\begin{array}{l}3.54 \\
3.57 \\
3.60\end{array}$ & $\begin{array}{l}1.01 \\
0.95 \\
0.82\end{array}$ & $\begin{array}{l}2.88 \mathrm{a} \\
3.10 \mathrm{~b} \\
3.37 \mathrm{c}\end{array}$ & $\begin{array}{l}0.78 \\
0.69 \\
0.69 \\
\end{array}$ & $\begin{array}{l}3.11 \\
3.31 \\
3.30 \\
\end{array}$ & $\begin{array}{l}0.90 \\
0.81 \\
0.78 \\
\end{array}$ \\
\hline $\begin{array}{l}\text { Household } \\
\text { size: } \\
1-2 \\
3-4 \\
5+ \\
\end{array}$ & $\begin{array}{r}95 \\
175 \\
55 \\
\end{array}$ & $\begin{array}{l}1.92 \mathrm{~d} \\
2.42 \mathrm{e} \\
1.94 \mathrm{f}\end{array}$ & $\begin{array}{l}0.92 \\
0.96 \\
0.84\end{array}$ & $\begin{array}{l}3.58 \\
3.52 \\
3.77 \\
\end{array}$ & $\begin{array}{l}1.06 \\
0.86 \\
0.88\end{array}$ & $\begin{array}{l}3.05 \mathrm{~d} \\
3.09 \mathrm{e} \\
3.38 \mathrm{f}\end{array}$ & $\begin{array}{l}0.78 \\
0.69 \\
0.71\end{array}$ & $\begin{array}{l}3.28 \\
3.29 \\
3.13\end{array}$ & $\begin{array}{l}0.78 \\
0.80 \\
0.97\end{array}$ \\
\hline $\begin{array}{l}\text { Age: } \\
-25 \text { yrs } \\
26-40 \\
41-55 \\
56-70+\end{array}$ & $\begin{array}{r}93 \\
129 \\
83 \\
19\end{array}$ & $\begin{array}{l}1.91 \mathrm{~g} \\
2.44 \mathrm{~h} \\
2.16 \\
2.05 \\
\end{array}$ & $\begin{array}{l}0.73 \\
1.02 \\
1.00 \\
1.04 \\
\end{array}$ & $\begin{array}{l}3.25 \mathrm{~g} \\
3.60 \mathrm{~h} \\
3.78 \mathrm{i} \\
4.20 \mathrm{j}\end{array}$ & $\begin{array}{l}0.99 \\
0.87 \\
0.82 \\
0.85 \\
\end{array}$ & $\begin{array}{l}3.08 \\
3.18 \\
3.03 \\
3.34 \\
\end{array}$ & $\begin{array}{l}0.67 \\
0.73 \\
0.77 \\
0.70\end{array}$ & $\begin{array}{l}3.27 \\
3.31 \\
3.16 \\
3.31\end{array}$ & $\begin{array}{l}0.85 \\
0.77 \\
0.88 \\
0.81\end{array}$ \\
\hline $\begin{array}{l}\text { Education: } \\
\text { Primary/ } \\
\text { Secondary } \\
\text { Tertiary }\end{array}$ & $\begin{array}{l}135 \\
190 \\
\end{array}$ & $\begin{array}{l}2.34 \mathrm{k} \\
2.091\end{array}$ & $\begin{array}{l}1.02 \\
0.90 \\
\end{array}$ & $\begin{array}{l}3.57 \\
3.59 \\
\end{array}$ & $\begin{array}{l}0.89 \\
0.96\end{array}$ & $\begin{array}{l}3.15 \\
3.12 \\
\end{array}$ & $\begin{array}{l}0.74 \\
0.72 \\
\end{array}$ & $\begin{array}{l}3.18 \\
3.32 \\
\end{array}$ & $\begin{array}{l}0.92 \\
0.75 \\
\end{array}$ \\
\hline $\begin{array}{l}\text { Income: } \\
\text { Lower } \\
\text { Middle } \\
\text { Upper }\end{array}$ & $\begin{array}{r}21 \\
179 \\
125 \\
\end{array}$ & $\begin{array}{l}2.58 \mathrm{~m} \\
2.38 \mathrm{n} \\
1.85 \mathrm{o} \\
\end{array}$ & $\begin{array}{l}1.08 \\
0.95 \\
0.85 \\
\end{array}$ & $\begin{array}{l}3.33 \\
3.44 \mathrm{n} \\
3.810 \\
\end{array}$ & $\begin{array}{l}1.17 \\
0.82 \\
0.99\end{array}$ & $\begin{array}{l}3.65 \mathrm{~m} \\
3.09 \mathrm{n} \\
3.09 \mathrm{o}\end{array}$ & $\begin{array}{l}0.78 \\
0.68 \\
0.76 \\
\end{array}$ & $\begin{array}{l}3.12 \\
3.20 \\
3.38 \\
\end{array}$ & $\begin{array}{l}0.90 \\
0.84 \\
0.78\end{array}$ \\
\hline $\begin{array}{l}\text { Gender: } \\
\text { Male } \\
\text { Female }\end{array}$ & $\begin{array}{l}140 \\
183\end{array}$ & $\begin{array}{l}2.32 p \\
2.10 q\end{array}$ & $\begin{array}{l}0.96 \\
0.95\end{array}$ & $\begin{array}{l}3.59 \\
3.56\end{array}$ & $\begin{array}{l}0.96 \\
0.91\end{array}$ & $\begin{array}{l}3.09 \\
3.16\end{array}$ & $\begin{array}{l}0.72 \\
0.74\end{array}$ & $\begin{array}{l}3.32 \\
3.21\end{array}$ & $\begin{array}{l}0.77 \\
0.86\end{array}$ \\
\hline $\begin{array}{l}\text { Total } \\
\text { Sample }\end{array}$ & 326 & 2.20 & 0.96 & 3.58 & 0.93 & 3.13 & 0.93 & 3.26 & 0.82 \\
\hline $\begin{array}{l}\text { Significant } \\
\text { Differences: } \\
\text { Language } \\
\text { Household S } \\
\text { Age } \\
\text { Education } \\
\text { Income } \\
\text { Gender }\end{array}$ & & $\begin{array}{l}* * \text { ab ac } \\
* * \text { de ef } \\
* * \text { gh } \\
*_{k l} \\
{ }^{* *} \text { mo n } \\
* * \mathrm{pg}\end{array}$ & & $\begin{array}{l}\text { **gi gj; } \\
*^{* *} \text { no }\end{array}$ & * gh ij & $\begin{array}{l}* * a c ; \\
* * \\
{ }^{*} \mathrm{df} \text { ef }\end{array}$ & & & \\
\hline
\end{tabular}

Lower case letters indicate significant differences according to ANOVA Scheffé Tests or T-tests.

$\left({ }^{*} \mathrm{p}<0.05,{ }^{* *} \mathrm{p}<0.01\right)$ 
From Table 3 it can be seen that male Xhosa speaking respondents, from a household size of three to four, in the 26 to 40 year age bracket, with a primary school education, and from the lower income group regarded money as an important power/prestige factor.

With regard to factor two it seems that retention time scored highest amongst elderly respondents in the upper income group. This may imply that these people regard saving money as an important investment for the future. Factor three (distrust/anxiety) represents a "worrying attitude" towards personal money matters. Here it seems as though Xhosa speaking respondents in the lower income bracket from large households, are most worrisome and careful about spending money. As far as money expenditure is associated with quality goods (factor four), English speaking upper income respondents with a tertiary education scored the highest on this factor. It is interesting to note though, that no significant relationships exist between factor four and the various sociodemographical variables. This indicates the homogeneity of the factor amongst the socio-demographic variables.

Table 4 Analysis of variance to determine relationships between sociodemographic variables and money attitudes

\begin{tabular}{|c|c|c|c|c|c|c|c|c|c|}
\hline \multirow{2}{*}{$\begin{array}{l}\text { Demo- } \\
\text { graphic } \\
\text { Variables }\end{array}$} & \multirow[b]{2}{*}{ df } & \multicolumn{2}{|c|}{$\begin{array}{l}\text { Factor } 1 \\
\text { Power/Prestige }\end{array}$} & \multicolumn{2}{|c|}{$\begin{array}{l}\text { Factor } 2 \\
\text { Retention/Time }\end{array}$} & \multicolumn{2}{|c|}{$\begin{array}{l}\text { Factor 3: Dis- } \\
\text { trust/Anxiety }\end{array}$} & \multicolumn{2}{|c|}{$\begin{array}{l}\text { Factor } 4 \\
\text { Quality }\end{array}$} \\
\hline & & $\mathbf{F}$ & $\mathbf{p}$ & & $\mathbf{p}$ & $\mathbf{F}$ & $\mathbf{p}$ & $\mathbf{F}$ & $\mathbf{p}$ \\
\hline Language & 2 & 21.6 & $0.0000^{* *}$ & 0.1 & 0.8420 & 7.0 & $0.0010^{* *}$ & 3.1 & $0.0445^{*}$ \\
\hline $\begin{array}{l}\text { House- } \\
\text { hold size }\end{array}$ & 2 & 7.97 & $0.0004^{* *}$ & 2.4 & 0.886 & 2.2 & 0.1060 & 1.1 & 0.3224 \\
\hline Income & 1 & 4.26 & $0.0150^{*}$ & 4.4 & $0.0120^{*}$ & 3.4 & $0.0322^{*}$ & 3.5 & $0.0290^{*}$ \\
\hline Age & 2 & 1.95 & 0.1213 & 8.7 & $0.0000^{* *}$ & 1.7 & 0.1535 & 0.8 & 0.4860 \\
\hline Education & 3 & 0.89 & 0.3457 & 1.9 & 0.1665 & 0.0 & 0.8757 & 0.3 & 0.5759 \\
\hline Gender & 1 & 2.51 & 0.1145 & 0.0 & 0.8498 & 0.7 & 0.3967 & 0.8 & 0.3546 \\
\hline Error & 310 & \multicolumn{8}{|c|}{${ }^{*} \mathrm{p}<0.05 ;{ }^{* *} \mathrm{p}<0.01$} \\
\hline
\end{tabular}

Table 4 shows which of the socio-demographic variables are significantly related to factor scores. From Table 4 it can be seen that language is significantly related to power/prestige (factor one), distrust/anxiety (factor three) and quality (factor four); household size is significantly related to power/prestige (factor one); age significantly related to retention/time (factor 
significantly related to all four factors (power/prestige, retention/time, distrust/anxiety and quality).

Table 3 shows significant differences between language groups, household size, age, education and income groups as well as between males and females for factor one (power/prestige). Age and income categories differ significantly on factor two (retention/time) while language categories, household size and income groups differ significantly on factor three (distrust/anxiety).

The differences observed in Table 3 indicate the important role which money plays in consumers' perceptions and attitudes of how it may influence their life style. For example, respondents with a primary school education hold significantly different views on how the power/prestige value of money may influence their lives, in comparison to those with a tertiary education. Likewise, low-income respondents regard the power/prestige and distrust/anxiety value of money as significantly different from upper income respondents.

The fact that significant differences were observed between language and income groups on two of the factors (power/ prestige and anxiety/distrust) on the attitude scale, further suggests the different underlying influence of cultural and economic factors on the money construct.

A comparison of the results of the present study with those of Medina, Saegert and Gresham (1996) shows that while these authors found significant differences between Anglo and Mexican Americans on the retention/time and quality factors, our study shows significant differences between Afrikaans, English and Xhosa speaking South Africans on the power/prestige and distrust/anxiety factors. Although it lies beyond the scope of this study to speculate about reasons for these differences, the results of both studies suggest the underlying role of cultural influences.

Hypothesis testing: Based on the findings of the present study, the design hypothesis stating that significant differences exist between the attitudes towards money amongst the three language groups in the sample, may be partially accepted. Significant differences were in fact observed on three of the four factors of the attitude scale. 


\section{CONCLUSION}

The main objective of this study was to compare attitudes towards money among English, Afrikaans and Xhosa speaking consumers in the Eastern Cape province of South Africa. The study was initiated by the observed declining saving pattern and increase in debt amongst consumers in general and more particular in the Eastern Cape. This trend of dissaving has made South Africa's domestic economy highly dependent on foreign investment. Excessive debt and lack of saving is often indicative of poor personal money management. Because consumer organisations recognise the important role they have to play in educating consumers in a broad spectrum of consumer issues, including how to practice sound personal money matters, the Consumer Protection Committee of the Eastern Cape spearheaded this research project.

It is important to recognise that the findings of the study are pertinent only to consumers in the region and not necessarily to the larger consumer population. The study was based on similar research carried out in the United States (Yamauchi \& Templer, 1982; Medina, Saegert and Gresham, 1996) and used a modified version of a measuring instrument (MAS) developed by these researchers. Due to vast differences in the sample populations of the present study and the studies carried out abroad, only limited comparisons could be made.

The results of the present study do show that the money attitude scale (MAS) can be used as a reliable instrument for the measurement of attitudes towards money in South Africa. All items loaded significantly on the applicable scale and the Cronbach's coefficient alphas all fell within an acceptable range. Furthermore, all the factors on the scale correlated moderately significantly positive with the exception of power/prestige (factor one) and retention/time (factor two), where a negative correlation was observed.

Three of the factors on the money attitude scale significantly relate to the three language groups, namely, power/prestige (factor one), anxiety/distrust (factor three), and quality (factor four). Xhosa speaking respondents scored significantly higher than the other language groups on both power/prestige and anxiety/distrust. This finding partially supports the design hypothesis that significant differences between the language groups do occur regarding money attitudes.

All the factors on the money attitude scale relate significantly to income. Lower income groups scored significantly higher on power/prestige (factor one) and distrust/anxiety (factor three) than did middle and upper income groups, whilst 
the upper income group scored significantly higher on retention/time (factor two) than the middle income group.

The findings suggest the presence of an underlying influence of cultural and economic factors on attitudes towards money. This supports the notion by Kaufman (1977) that the symbolic meaning of money to an individual is largely determined by his culture, religion and life experiences. Our results show that Xhosa speaking respondents in the low income bracket and from large households, experience more anxiety and distrust when spending money, whilst Afrikaans speaking respondents in the middle to upper income bracket from small households worry least about money.

It is interesting to observe that retention/time (factor two) scored the high average value of 3.58 on the five-point scale, the highest of all factors. This contradicts the statistics (Swart 1997) which indicate that personal saving has declined drastically over the last decade. It either implies that respondents overestimate their financial planning and saving behaviour, or that they lack the income to save despite the motivation to do so.

Considering attempts by consumer organisations to empower consumers to become responsible citizens when consuming scarce natural and economic resources, the findings of this study may serve as a guideline for developing educational programmes on personal money management. The benefits of financial planning and saving for future events, need to be emphasised in particular. Educators also need to be particularly sensitive to cultural differences and economic conditions when targeting specific consumer groups in this context.

Finally, the results and implications of the study should be seen as a first step in gaining knowledge on consumer attitudes towards money in the multi-cultural context of the new South Africa. Follow-up studies with larger samples in different areas of the country need to be done to verify the tentative trends observed in this investigation. 


\section{REFERENCES}

1 BAKER, W.E., \& JIMERSON, J.B. (1992) "The Sociology of Money", American Behavioral Scientist, 35: 678-93.

2 BORNEMANN, E. (1976) The Psychoanalysis of Money, Urizen Books, New York.

3 CRUMP, T. (1992) "Money as a Ritual System", American Behavioral Scientist, 35: 669-77.

4 DAVEL, G. (1996) "Rural Savings: Nowhere to Go", Financial Mail, December 6, 41 .

5 DU PLESSIS, P.J., ROUSSEAU, G.G. and BLEM, N.N. (1995) Buyer Behaviour Strategic Marketing Applications, Southern Book Publications, Halfway House, SA.

6 DOYLE, K.O. (1992) "Toward the Psychology of Money", American Behavioral Scientist, 35: 708-24.

7 FINN, D.R. (1992) "The Meaning of Money - A View from Economics", American Behavioral Scientist, 35: 658-68.

8 FRANE J., JENRICH, R.I. and SAMSON, P.F. (1979) "BMDP 4M", In W.J. Dixon and M.B. Brown (ed.) BMDP Statistical Software: 656-84, University of California Press, Berkley.

9 GRESHAM, A. \& FONTENOT, G. (1989) "The Differing Attitudes of the Sexes Toward Money: An Application of the Money Attitude Scale", In Gordon, P.J. \& Kellerman, B.J. (eds.) Advances in Marketing, Southwestern Marketing Association.

10 KAUFMAN, W. (1977) "Some Emotional Uses of Money", Contribution 11 In Bornemann, E., The Psychoanalysis of Money, Urizen Books, New York.

11 MEDINA, J.F., SAEGERT, J. and GRESHAM, A. (1996) "Comparison of Mexican-American and Anglo-American Attitudes Toward Money", Journal of Consumer Affairs: $30,1,124-45$.

12 MALHOTRA, N. (1996) Marketing Researcher: An Applied Orientation 2nd. ed., Prentice Hall, New Jersey.

13 MALHOTRA, N., AGARWAL, J. and PETERSON, M. (1996) "Methodological Issues in Cross-Cultural Marketing Research", International Marketing Review: 13, 5, 7-43.

14 PENALOZA, L. (1994) "Altravesando Fronteras/Border Crossings: A Critical Ethnographic Exploration of the Consumer Acculturation of Mexican Immigrants", Journal of Consumer Research, 21: 32-54.

15 ROUSSEAU, G.G. \& VENTER, D.J.L. (1996) "A Comparative analysis of Consumer Awareness in South Africa During 1992 and 1994. Implications for the Reconstruction and Development Programme (RDP)", Journal of Industrial Psychology: 22, 2, 26-31. 
16 SWART, H. (1997) "Suid-Afrika nou Vierkantig binne Skuldstrik", Die Burger, 10 Maart: 8.

17 TANG, T.L. (1992) "The Meaning of Money Revisited", Journal of Organizational Behaviour, 13: 197-202.

18 TANG, T.L. (1993) "The Meaning of Money: Extension and Exploration of the Money Ethic Scale in a Sample of University Students in Taiwan", Journal of Organizational Behaviour, 14: 93-9.

19 VISAGIE, D. (1977) ' $n$ Bedryfsielkundige ondersoek na die betekenis van geld: ' $n$ Vergelykende Studie tussen Blanke en Kleurlingstudente, University of Stellenbosch, MCom Dissertation.

20 YAMAUCHI, K.T. \& TEMPLER, D.I. (1982) "The Development of a Money Attitude Scale", Journal of Personality Assessment, 46, May: $522-8$. 